\title{
Correction to: Resveratrol oligomer structure in Dipterocarpaceaeous plants
}

\author{
Tetsuro Ito $^{1,2}$
}

Published online: 30 May 2020

(c) The Author(s) 2020

\section{Correction to: Journal of Natural Medicines https://doi.org/10.1007/s11418-020-01412-x}

The article Resveratrol oligomer structure in Dipterocarpaceaeous plants, written by Tetsuro Ito, was originally published electronically on the publisher's internet portal on 30 April 2020 without open access. With the author(s)' decision to opt for Open Choice the copyright of the article changed on 22 May 2020 to () The Author(s) 2020 and the article is forthwith distributed under a Creative Commons Attribution 4.0 International License (https://creativeco mmons.org/licenses/by/4.0/), which permits use, sharing, adaptation, distribution and reproduction in any medium or format, as long as you give appropriate credit to the original author(s) and the source, provide a link to the Creative Commons licence, and indicate if changes were made.

The original article was updated.
The original article can be found online at https://doi.org/10.1007/ s11418-020-01412-x.

\section{Tetsuro Ito}

tito@u-gifu-ms.ac.jp

1 Laboratory of Pharmacognosy, Gifu Pharmaceutical University, 1-25-4 Daigaku-nishi, Gifu 501-1196, Japan

2 Present Address: Laboratory of Pharmacognosy, Department of Pharmacy, Faculty of Pharmacy, Gifu University of Medical Science, 4-3-3 Nijigaoka, Kani, Gifu 509-0293, Japan
Open Access This article is licensed under a Creative Commons Attribution 4.0 International License, which permits use, sharing, adaptation, distribution and reproduction in any medium or format, as long as you give appropriate credit to the original author(s) and the source, provide a link to the Creative Commons licence, and indicate if changes were made. The images or other third party material in this article are included in the article's Creative Commons licence, unless indicated otherwise in a credit line to the material. If material is not included in the article's Creative Commons licence and your intended use is not permitted by statutory regulation or exceeds the permitted use, you will need to obtain permission directly from the copyright holder. To view a copy of this licence, visit http://creativecommons.org/licenses/by/4.0/.

Publisher's Note Springer Nature remains neutral with regard to jurisdictional claims in published maps and institutional affiliations. 